\title{
Livin mediates tumor cell invasion in the DU-145 cell line via NF-кB
}

\author{
FENG CHEN $^{1 *}$, DEYONG YANG ${ }^{1,2^{*}}$, XIANGYU CHE $^{1}$, JIANBO WANG $^{1}$, \\ XIANCHENG LI ${ }^{1}$, ZHIWEI ZHANG ${ }^{1}$, XIAOCHI CHEN ${ }^{1}$ and XISHUANG SONG ${ }^{1}$ \\ ${ }^{1}$ Department of Urology, First Affiliated Hospital of Dalian Medical University, Dalian 116011; \\ ${ }^{2}$ Department of Biomedical Engineering, Dalian University of Technology, Dalian 116024, P.R. China
}

Received October 24, 2011; Accepted January 3, 2012

DOI: $10.3892 / o r .2012 .1730$

\begin{abstract}
Livin is a member of the family of inhibitors of apoptosis proteins (IAPs) and tumor cell invasion is a general property of multiple IAPs. Livin is highly expressed in prostate cancer (PCa) tissues. Livin overexpressing cells are more resistant to apoptotic stimuli than normal cells. Thus, aberrantly increased cell survival is an invariable requirement of metastasis. In this study, we investigated whether livin signaling affects metastasis by transfecting siRNA targeting livin into the DU-145 prostate cancer cell line to confirm the anti-invasion effect and blockade of the livin gene. We found that livin knockdown inhibited DU-145 prostate carcinoma cell invasion. We investigated how livin promotes tumor cell invasion, and found that livin induction of fibronectin contributed to tumor cell invasion. In addition, we found that livin induction of fibronectin regulates tumor cell invasion via nuclear factor $\kappa \mathrm{B}(\mathrm{NF}-\kappa \mathrm{B})$ signaling. These data showed that livin, as a gene directly promoting metastasis, can be useful for therapeutic intervention against advanced and disseminated PCa.
\end{abstract}

\section{Introduction}

Prostate cancer (PCa) is the third most common cancer and the second leading cause of cancer death for males in Western countries (1). There has been a recent trend in Asia towards increasing incidence of PCa, with some low-risk regions, such as Japan and Singapore, reporting a more rapid increase than high-risk countries in the recent years (2). PCas are generally slow-growing malignancies that are characterized by an imbalance in the rates of cell division and cell death. Tissue kinetics studies indicate that insufficient programmed cell death represents the chief explanation for the gradual accumulation of prostate cancer cells in vivo in humans (3). Progression of

Correspondence to: Professor Xishuang Song, Department of Urology, First Affiliated Hospital of Dalian Medical University, No. 222 Zhongshan Road, Dalian 116011, P.R. China

E-mail: songxishuang@gmail.com

${ }^{*}$ Contributed equally

Key words: livin, DU-145 prostate carcinoma cell, fibronectin, nuclear factor $\kappa \mathrm{B}$, tumor invasion, prostate cancer localized hormone-dependent prostate cancers to metastatic, hormone-refractory disease is also associated with dysregulation of normal apoptotic mechanisms. Thus, aberrantly increased cell survival is an invariable requirement of metastasis (4), and is typically contributed via deregulated expression of Bcl-2 (5) or inhibitor-of-apoptosis (IAP) (6) cytoprotective proteins. However, some of these molecules, especially IAPs, have recently emerged as broader regulators of cellular homeostasis, with functions extending beyond apoptosis inhibition (7).

Livin is a member of IAPs family that is conserved across species ranging from yeasts to mammals (8-11). The antiapoptotic activity of livin is mediated through the inhibition of caspase-3, -7, and -9, as well as by its E3 ubiquitin-ligase-like activity that promotes degradation of Smac/DIABLO, a critical endogenous regulator of all IAPs $(12,13)$. As with other IAP members, livin has also been linked to the activation of multiple gene expression networks including JNK1 by transforming growth factor h-activated kinase 1 (TAK1)/TAK1-binding protein (TAB1) signaling cascade (14) and the wingless and integration site growth factor (Wnt)/h-catenin signaling pathway (15).

Livin overexpression cells are more resistant to apoptotic stimuli than normal cells $(10,16)$. To date, livin expression was significantly increased in a series of cancers (17-20). Song et al (21) showed that the livin was highly expressed in $\mathrm{PCa}$ tissues. Recently Mehrotra and Languino have shown that intermolecular cooperation between IAP proteins, XIAP and survivin, promotes tumor cell invasion in vitro and metastatic dissemination in vivo (22). Thus, tumor cell invasion was a general property of multiple IAPs. In this study, to investigate whether livin signaling affected metastasis we used siRNA targeting to livin transfection into the DU-145 cancer cell line to confirm the anti-tumor-invasion effect and blockade of livin gene. These results suggested that livin knockdown inhibited DU-145 cell invasion. Next we identified that livin induction of fibronectin regulates tumor cell invasion via $N F-\kappa B$ signaling. These data showed livin as direct metastasis genes could be useful for therapeutic intervention against these targets in patients with advanced and disseminated PCa.

\section{Materials and methods}

siRNA design and preparation. The siRNAs were chemically synthesized (Genepharma, Shanghai, China). The 
target sequence of livin for production of siRNA was 5'-GGAGAGAGGTCCAGTCTGA-3' as previously described (23). To analyze the suppression of the fibronectin we used siRNA with the sequence 5'-GAACAAAGACAGAGACAA-3' and the siRNA sequences for p65 was 5'-GATTGAGGAGAAACG TAAATT-3' (24). The negative control siRNA with the sequence 5'-UUCUCCGAACGUGUCACGU-3' have no match to any known human gene. Briefly, siRNA was collected. Then resuspended to a stock concentration with $1 \mathrm{X}$ siRNA buffer (Genepharma). After $30 \mathrm{~min}$ at room temperature, the concentration of siRNA was verified using UV spectrophotometry at $260 \mathrm{~nm}$.

Cell culture. DU-145 cell line was obtained directly from the Cell Bank of Type Culture Collection of Chinese Academy of Sciences (Shanghai Institute of Cell Biology, Chinese Academy of Sciences, China) and maintained for less than 6 months in Dulbecco's modified Eagle's medium (DMEM) supplemented with $10 \%$ fetal calf serum (FCS), $100 \mathrm{U} / \mathrm{ml}$ penicillin, $100 \mathrm{mg} / \mathrm{ml}$ streptomycin, and $1 \mathrm{mM} \mathrm{L}$-glutamine at $37^{\circ} \mathrm{C}$ in an atmosphere of $5 \% \mathrm{CO}_{2}$.

Transient transfection. All of transfections in our study were carried out with Lipofectamine 2000 (Invitrogen, USA) according to the procedure recommended by the manufacturer. In brief, DU-145 cells were plated on 6-well plates (Costar, USA) at $60-80 \%$ confluency. The $5 \mu 1$ lipofectamine 2000 and 50 pmol of individual siRNAs were diluted in $250 \mu \mathrm{l}$ DMEM without FCS, respectively and mixed in a final volume of $500 \mu \mathrm{l}$ transfection solution. After $20 \mathrm{~min}$, the transfection solution was added into cells supplemented with $2.0 \mathrm{ml}$ DMEM containing $10 \%$ FCS. After $24 \mathrm{~h}$, the transfection solution culture media were refreshed with DMEM with $10 \%$ FCS. To test siRNA and cDNA transfection efficiency, we used fluorescence-labeled siRNA before doing experiments. The transfection efficiencies were assessed as $>80 \%$ in the transfection experiments (data not shown). The cells were harvested after $48 \mathrm{~h}$ for subsequent protein analysis.

MTT assay. DU-145 cells in logarithmic growth phase were seeded in 96 -well plates at $5 \times 10^{4}$ cells per well. Then cells were transfected with siRNA of different concentrations (the final concentrations are $0,25,50,100,150,200 \mathrm{nmol} / \mathrm{l}$ ) for $6 \mathrm{~h}$, followed by culturing with normal medium for $72 \mathrm{~h}$. Four hours before the end of culture, $20 \mu \mathrm{l}$ of $5 \mathrm{mg} / \mathrm{ml} \mathrm{MTT}$ (Sigma, USA) was added to the culture medium. After incubation, the culture medium was removed and $200 \mu \mathrm{l}$ of dimethylsulphoxide (DMSO) was added to resolve the crystal. Absorbance was measured at $490 \mathrm{~nm}$. Each sample was assayed 4 times.

Reverse transcription-PCR. Total RNA was extracted from cell lysates with TRIzol reagent (Invitrogen) and RT-PCR was carried out with a RNA PCR kit Ver. 3.0 (Takara, Japan) according to the kit instructions. Livin-specific primers were: forward, 5'-GTCCCTGCCTCTGGGTAC-3'; reverse, 5'-CAGGGAGCCCACTCTGCA-3'. Product sizes $368 \mathrm{bp}$. The primers used for GAPDH were: forward, Sense: 5'-ATGACATCAAGAAGGTGGTG-3'; reverse, 5'-CATACC AGGAAATGAGCTTG-3', which yields a product of $177 \mathrm{bp}$.

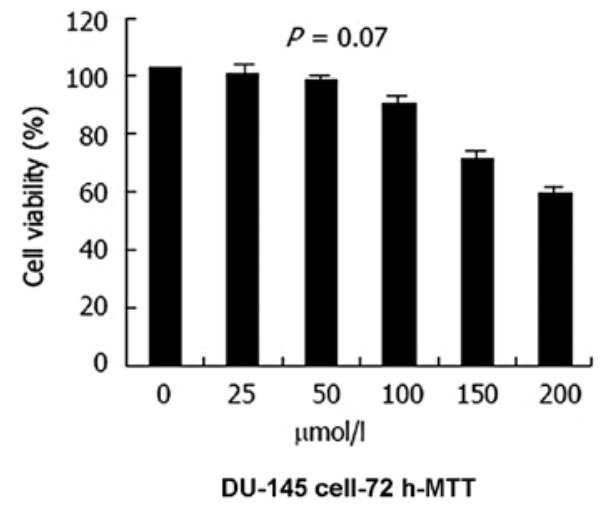

Figure 1. MTT assay after small interfering RNA transfection in DU-145 cell line at 72-h post-transfection. The proliferation of cells transfected with siRNA was inhibited at $200 \mu \mathrm{mol} / 1$ concentration $(\mathrm{P}=0.07)$.

The PCR condition was: $95^{\circ} \mathrm{C}$ for $2 \mathrm{~min}$, then 38 cycles at $94^{\circ} \mathrm{C}$ for $30 \mathrm{sec}, 64^{\circ} \mathrm{C}$ for $45 \mathrm{sec}$, and $72^{\circ} \mathrm{C}$ for $30 \mathrm{sec}$ in $1.5 \mathrm{mM}$ $\mathrm{MgCl}_{2}$-containing reaction buffer. RT-PCR products $(5 \mu \mathrm{l})$ were resolved on $1.5 \%$ agarose gels. The gels were stained with ethidium bromide (EB) and were scanned for densitometric estimation of the livin products with GAPDH products serving as the internal control.

Western blot analysis. Cultured cells, washed with cold PBS, were extracted with lysis buffer supplemented with protease inhibitors, phosphatase inhibitors and PMSF. Lysates were vortexed for $15 \mathrm{~min}$ at $4^{\circ} \mathrm{C}$ and centrifuged at $14,000 \mathrm{x} \mathrm{g}$ for $15 \mathrm{~min}$ at $4^{\circ} \mathrm{C}$ and supernatants collected heated at $95^{\circ} \mathrm{C}$ for $5 \mathrm{~min}$. Proteins $(15-30 \mu \mathrm{g})$ were separated by $12 \%$ SDS poly-acrylamide gel electrophoresis, transferred to a nitrocellulose membrane (Millipore, USA). The membrane were blocked at $4^{\circ} \mathrm{C}$ overnight with blocking buffer $(5 \%$ nonfat milk powder in Tris-buffered saline contained $0.5 \%$ Tween-20) and incubated for $3 \mathrm{~h}$ with a monoclonal anti-livin antibody, a monoclonal anti-fibronectin antibody, a monoclonal anti-I $\kappa \mathrm{B} \alpha$, and a monoclonal anti-phosphorylated $-\mathrm{I} \kappa \mathrm{B} \alpha$, a monoclonal anti-p65 subunit of $\mathrm{NF}-\kappa \mathrm{B}$ antibody or a monoclonal anti- $\beta$-actin antibody (all from Santa Cruz Biotechnology, USA), employing enhanced chemiluminescence (Pierce, USA). The reactivity was detected with ECL Plus $^{\mathrm{TM}}$ Western blot detection reagents (RPN2132, Amersham, Buckinghamshire, UK).

Cell migration and invasion. Analysis of cell migration was carried out using $6.5-\mathrm{mm}$ Transwell chambers $(8-\mu \mathrm{m}$ pore size; Costar). Inserts were prepared by coating the upper and lower surfaces with $15 \mu \mathrm{g} / \mathrm{ml}$ collagen (Cohesion, Palo Alto, CA) for $18 \mathrm{~h}$ at $4^{\circ} \mathrm{C}$, followed by a blocking step with DMEM containing $0.25 \%$ heat-inactivated BSA for $1 \mathrm{~h}$ at $37^{\circ} \mathrm{C}$. In some experiments, Transwell inserts were left uncoated. The cells were harvested, suspended in DMEM containing $0.25 \%$ heat-inactivated BSA, and added $\left(1 \times 10^{5}\right)$ to the upper chamber, with aliquots of conditioned medium collected from NIH3T3 fibroblasts placed in the lower chamber as chemoattractant. After $1 \mathrm{~h}$ of incubation, non-migrating cells were removed mechanically from the upper chamber using a cotton swab. Cells migrated to the lower surface of 
A

Livin

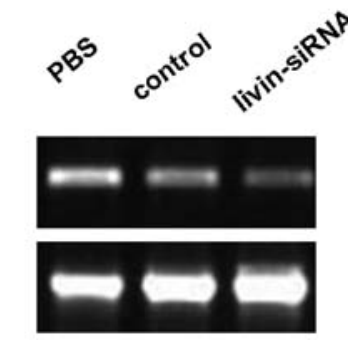

368 bp

$177 \mathrm{bp}$
B

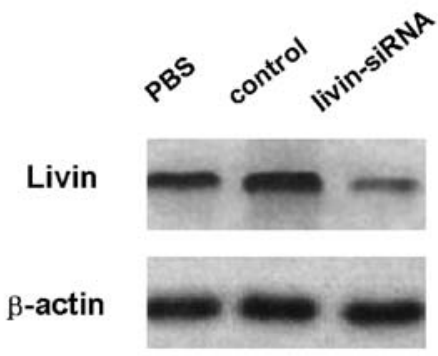

Figure 2. Livin mRNA and protein expression was inhibited after livin siRNA transfection DU-145 cells were transfected with control siRNA (Ctrl) or livintargeted siRNA and after 48 h DU-145 cells were analyzed for RT-PCR or Western blotting. (A) The livin mRNA was decrease significantly in livin-siRNA group compared with the one in control group and PBS group while the last two groups were similar. (B) The livin protein was decrease significantly in livin-siRNA group compared with the one in control group and PBS group while the last two groups were similar.

the Transwell membrane were fixed in methanol for $10 \mathrm{~min}$ at $22^{\circ} \mathrm{C}$, and membranes were mounted on glass slides using Vectashield mounting medium containing DAPI (Vector Laboratories, Burlingame, CA). Cell migration was quantified by counting the number of stained nuclei in five individual fields in each Transwell membrane, by fluorescence microscopy, in duplicate.

For analysis of cell invasion, the upper Transwell chamber (8- $\mu \mathrm{m}$ pore size; Costar) was coated with $0.5 \mu \mathrm{g}$ Matrigel (Collaborative Research, Bedford, MA) diluted in cold water, and allowed to air dry. After $1 \mathrm{~h}$ of incubation with DMEM, the DU-145 cells $\left(1 \times 10^{5}\right)$ were added to the upper chamber for $6-24 \mathrm{~h}$ at $37^{\circ} \mathrm{C}$. Cells that had invaded the lower surface of the membrane were fixed with methanol, stained with DAPI, and quantified by fluorescence microscopy.

Promoter activity. DU-145 cells were seeded into a 48-well plate $24 \mathrm{~h}$ before transfection. For each well, cells were transiently cotransfected with $0.1 \mu \mathrm{g}$ of a NF- $\kappa \mathrm{B}$ reporter construct $(\mathrm{pNF}-\kappa \mathrm{B})$ or a control reporter plasmid (pControl) (Panomics Inc., Fremont, $\mathrm{CA}$ ), together with $0.06 \mu \mathrm{g}$ of $\beta$-galactosidase reporter vector (Promega, Madison, WI), which was used to normalize NF- $\kappa \mathrm{B}$ reporter gene activity, using Lipofectamine 2000 (Invitrogen). In another experiment, we alternatively transiently transfected with a $1.9 \mathrm{~kb}$ fragment of the proximal fibronectin promoter fused to luciferase (pGL-Fib1900, given by Professor Dario C. Altieri, University of Massachusetts, Worcester, MA, USA), using Lipofectamine 2000. After $24 \mathrm{~h}$ at $37^{\circ} \mathrm{C}$, cells were harvested, and analyzed for $\beta$-galactosidasenormalized luciferase activity in a luminometer. In some experiments, $\beta$-galactosidase-normalized NF- $\kappa \mathrm{B}$ promoter activity in the DU-145 cells was examined in the presence or in the absence of TNF- $\alpha$ stimulation.

Electrophoretic mobility shift assay (EMSA). Nuclear extracts $(20 \mu \mathrm{g})$ prepared from DU-145 cell transfected with livin-siRNA or control siRNA were incubated without or with TNF- $\alpha$ in the presence of ${ }^{32} \mathrm{P} \gamma$-labeled 45-mer double-stranded $\mathrm{NF}-\kappa \mathrm{B}$ oligonucleotide derived from the human immunodeficiency virus long terminal repeat, 5'-TTGTTACAAGGGACTTTC CGCTGGGGACTTTCCAGGGAGGCGTGG-3'. Incubations were carried out in buffer containing $10 \mathrm{mM}$ Tris $\mathrm{HCl}$, pH 8.0, $150 \mathrm{mM} \mathrm{KCl,} \mathrm{0.5} \mathrm{mM} \mathrm{EDTA,} \mathrm{0.1 \%} \mathrm{Triton-X} \mathrm{100,}$ $12.5 \%$ glycerol (v/v), $0.2 \mathrm{mM}$ DTT for $1 \mathrm{~h}$ at $22^{\circ} \mathrm{C}$. Poly$\mathrm{dIdC}$ (Sigma) and sonicated salmon sperm DNA (Stratagene) were added to block non-specific binding. DNA-protein complexes were separated by electrophoresis on $5 \%$ native polyacrylamide gels, and radioactive bands were visualized by autoradiography. A double-stranded ${ }^{32} \mathrm{P} \gamma$-labeled mutant oligonucleotide, 5'-TTGTTACAACTCACTTTCCGCTGCT CACTTTCCAGGGAGGCGTGG-3', or wild-type unlabeled oligonucleotide was used for competition studies. The samples were analyzed by autoradiography.

Real-time PCR assay. Fibronectin mRNA expression was measured by real-time PCR with the primer set as follows: sense, 5'-TTATGACGACGGGAAGACCT-3'; and antisense, 5'-GCTGGATGGAAAGATTACTC-3'. It then was normalized by GAPDH mRNA expression with the primer set as follows: sense, 5'-TGCACCACCAACTGCTTAGC-3'; and antisense, 5'-GGCATGGACTGTGGTCATGAG-3'. Real-time PCR was performed with SYBR green I (1:20,000; Qiagen) with one cycle at $95^{\circ} \mathrm{C}$ for $3 \mathrm{~min}$ followed by 40 cycles of $95^{\circ} \mathrm{C}$ for $45 \mathrm{sec}$, $61^{\circ} \mathrm{C}$ for $45 \mathrm{sec}, 72^{\circ} \mathrm{C}$ for $40 \mathrm{sec}$, and $80^{\circ} \mathrm{C}$ for $5 \mathrm{sec}$.

\section{Results}

Transfection of siRNA-livin to DU-145 cell line. To identify whether livin expression was affected by siRNA, we transfected siRNA at different concentrations $(25,50,100,150$ and $200 \mu \mathrm{mol} / \mathrm{l})$ to DU-145 cell line. After transfected with different concentrations of livin siRNA, the cellular viability was determined by MTT (Fig. 1). The MTT assay showed that, compared with controls, the proliferation of cells transfected with siRNA was remarkably inhibited at $200 \mu \mathrm{mol} / 1$ after transfection ( $\mathrm{P}=0.07)$, Accordingly, we chose $<200 \mu \mathrm{mol} / 1$ siRNA as the suitable concentration for further study.

Livin mRNA and protein expression is inhibited after livin siRNA transfection. To demonstrate the inhibitory effect of livin siRNA on livin expression, RT-PCR and Western blot were applied to detect the livin mRNA and protein expression level in the cells of each group in which we transfected siRNA at different $100 \mu \mathrm{mol} / 1$ concentrations as recommended to DU-145 cell line. In RT-PCR experiment, livin gene electrophoretic bands were seen at the positions of 368 bp relative to Marker in each group. However, the brightness of the electrophoretic bands in livin-siRNA groups were significantly less than the one in control siRNA group and PBS group; while the brightness of the last two groups were 
A

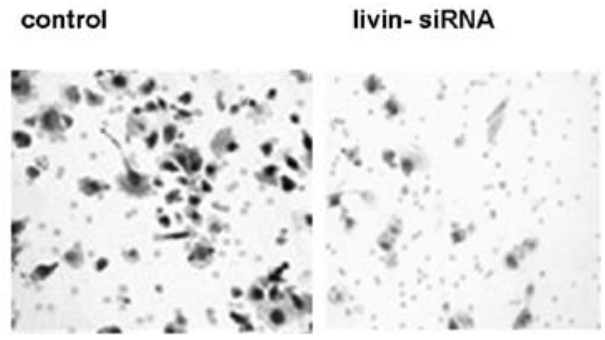

DU-145 cell
B

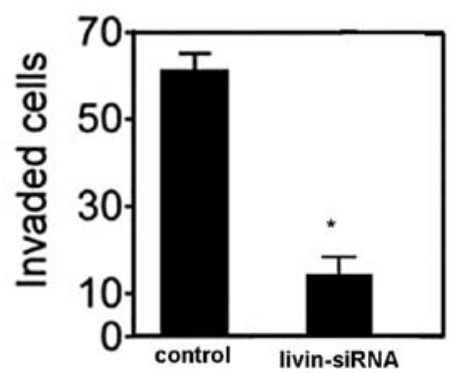

Figure 3. Livin targeting inhibits tumor cell invasion. DU-145 cells transfected with either the control siRNA or livin-targeted siRNA were analyzed for Matrigel invasion by DAPI staining and quantified. The cells were cultured in 6.5-mm Transwell chambers as described in Materials and methods. Cells that had invaded the lower surface of the membrane were fixed with methanol, stained with DAPI. (A) Images were recorded at a magnification of x100. (B) Cell migration was quantified by counting the number of stained nuclei in five individual fields in each Transwell membrane, by fluorescence microscopy, in duplicate. ${ }^{*} \mathrm{P}<0.0003$, compared with the control siRNA.

A

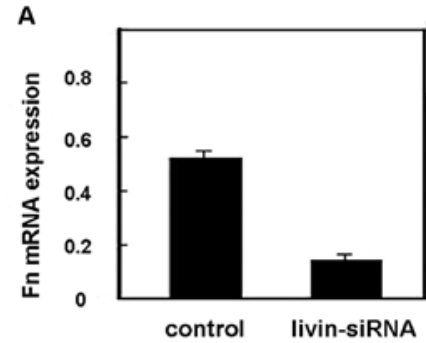

C

Fibronectin
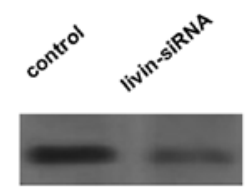

$\beta$-actin
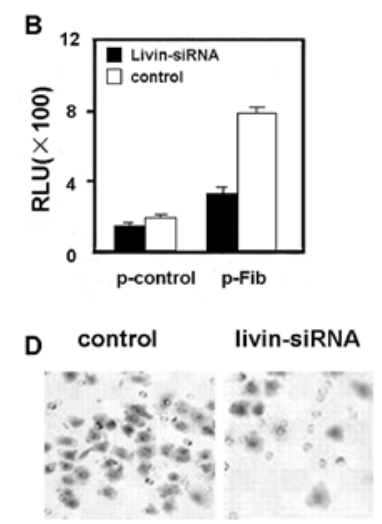

DU-145 cell

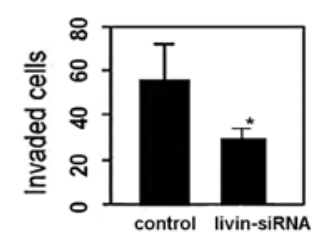

E

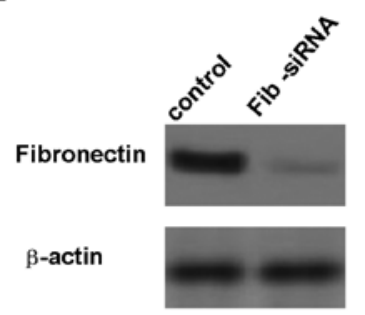

DU-145 cells transfected with livin-siRNA
$\mathbf{F}$

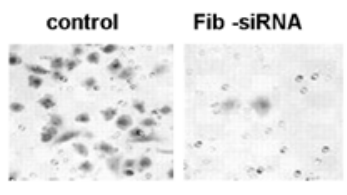

DU-145 cells transfected with livin-siRNA

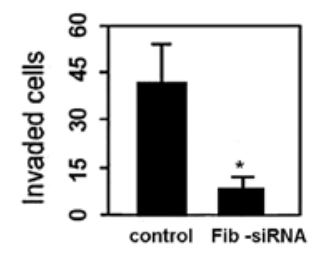

Figure 4. Livin induction of fibronectin regulates tumor cell invasion (A) DU-145 cells transfected with either the control siRNA or livin-targeted siRNA were analyzed for real-time PCR. RNA was amplified for fibronectin gene products, and normalized to GAPDH expression. (B) DU-145 cells transfected with p-control or a fibronectin promoter-luciferase construct (p-Fib) were analyzed after $24 \mathrm{~h}$ for $\beta$-galactosidase-normalized luciferase activity. RLU, relative luciferase units. (C) DU-145 cells were transfected with control siRNA(Ctrl) or livin-targeted siRNA and cell lysates (30 $\mu \mathrm{g})$ were subjected to Western blotting as described for fibronectin protein analysis. DU-145 cells exhibited dramatically increased fibronectin protein whereas livin-siRNA group showed less fibronectin protein expression. (D) DU-145 cells transfected with either the control siRNA or livin-targeted siRNA migration on uncoated Transwell inserts was analyzed by DAPI staining and quantified, in duplicate."P $<0.001$, compared with the control siRNA. (E) DU-145 cells were transfected with control siRNA (Ctrl) or fibronectin-targeted siRNA after transfection with livin-siRNA. Cell lysates (30 $\mu \mathrm{g}$ ) were subjected to Western blotting as described. (F) DU-145 cells transfected with either the control siRNA or fibronectin-targeted siRNA after transfection with livin-siRNA Matrigel invasion was analyzed by DAPI staining and quantified, in duplicate. $\mathrm{P}<0.001$, compared with the control siRNA.

similar (Fig. 2A). Then we performed Western blotting to evaluate livin protein expression. Confirmed with the results of RT-PCR, the expression of livin in the livin-siRNA groups were significantly lower than the ones in control siRNA group and PBS group, while the expression of livin in the last two groups were similar (Fig. 2B). Together, these data demonstrated that livin mRNA and protein expression were inhibited after livin-siRNA transfection.

Livin-mediated DU-145 tumor cell invasion. Tumor cell invasion has been repoted as a general property of multiple IAPs (22). To investigate whether livin-silencing induces tumor cell invasion, cell migration and invasion assay was used. We transfected livin-siRNA and control siRNA at $100 \mu \mathrm{mol} / 1$ concentration to DU-145 cell line. Transfection of DU-145 cell line with livin-siRNA suppressed the expression of the livin protein, but not vice versa, whereas a control siRNA had no such effect. Under these conditions, livin knockdown inhibited DU-145 cell invasion through Matrigel inserts, from 58.2 \pm 9.8 (control siRNA) to $12.5 \pm 2.1$ invaded cells per field $(\mathrm{P}=0.0003, \mathrm{n}=10)($ Fig. 3$)$ which indicated that livin-mediated DU-145 tumor cell invasion.

Livin induction of fibronectin regulates tumor cell invasion. We investigated how livin promote tumor cell invasion, by looking at the gene expression profile of DU-145 cells. DU-145 cells 

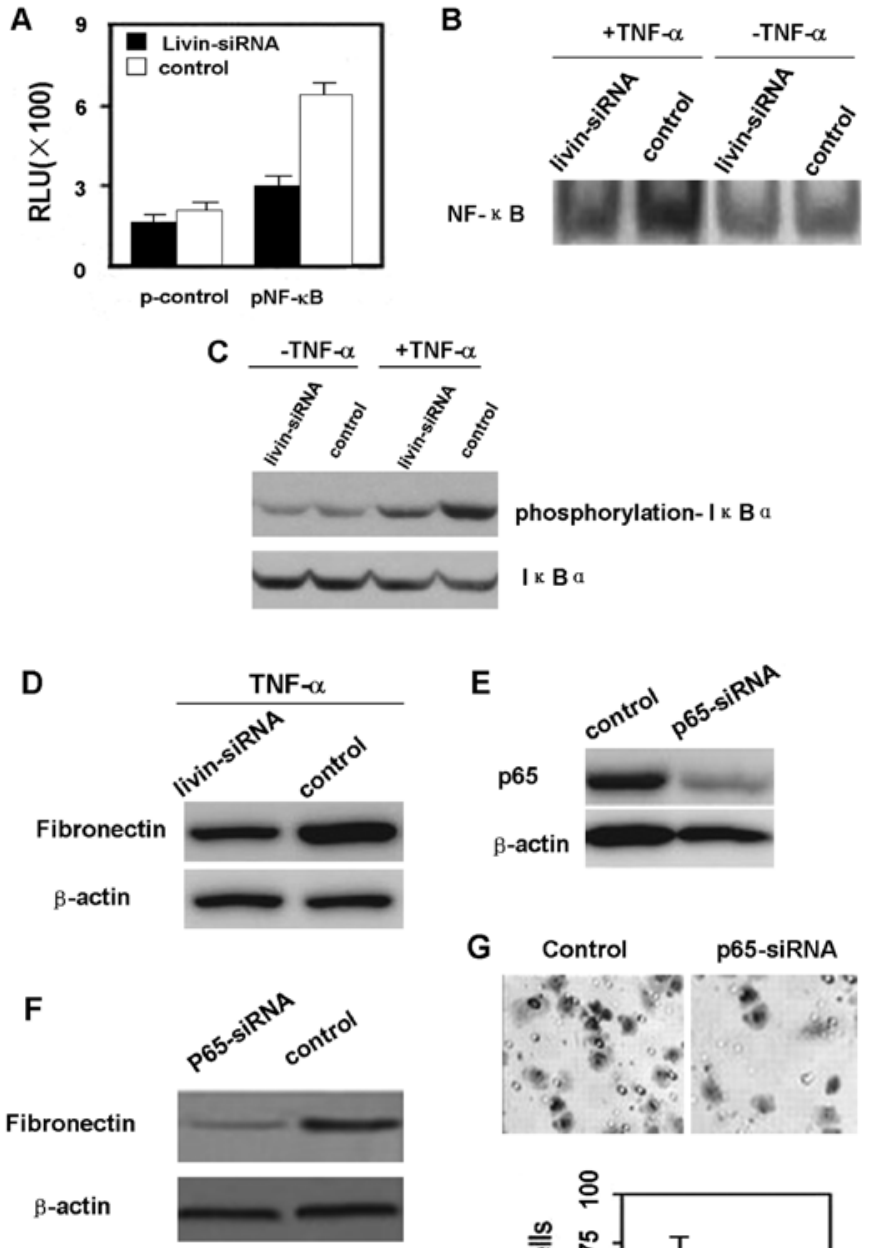

laminin 5 mRNAs were not significantly different in DU-145 cells in control group, compared to DU-145 cells transfected livin-siRNA (data not shown).

Consistent with these data, DU-145 cells transfected with control siRNA exhibited dramatically increased endogenous fibronectin protein content, by Western blotting (Fig. 4C) whereas DU-145 cells transfected with livin-siRNA showed less fibronectin protein expression. This newly produced fibronectin was released in the DU-145 cells and was sufficient to support tumor cell migration on Transwell inserts in the absence of exogenous substrate (Fig. 4D). In contrast, DU-145 cells transfected with livin-siRNA did not migrate in the absence of substrate (Fig. 4D).

Finally, we tested whether fibronectin contributed to tumor cell invasion. Herein, we transfected both siRNA targetedfibronectin and siRNA targeted-livin to DU-145 cell line (the MTT assay data not shown). The result indicated that siRNA knockdown of fibronectin in DU-145 cells transfected with livin-siRNA (Fig. 4E) significantly inhibited Matrigel invasion, as compared with DU-145 cells only transfected with livin-siRNA (Fig. 4F). From these data we deduced that fibronectin played an important role in livin-mediated tumor cell invasion.

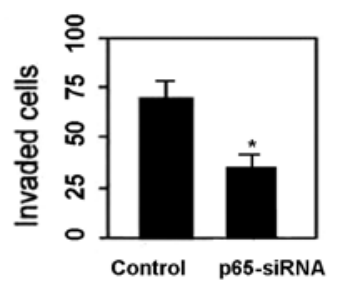

Figure 5. NFKB-induction of fibronectin contributes to livin-mediated tumor cell invasion. (A) With $3 \mathrm{~h} \mathrm{TNF}-\alpha$ treatment DU-145 cells transfected with $\mathrm{NF}-\kappa \mathrm{B}$ reporter construct (pNF- $\mathrm{kB}$ ) or a control reporter plasmid (pControl) were analyzed after $24 \mathrm{~h}$ for $\beta$-galactosidase-normalized luciferase activity. RLU, relative luciferase units. (B) Nuclear extracts $(20 \mu \mathrm{g})$ prepared from DU-145 cell transfected with control siRNA or livin-siRNA were incubated without or with TNF- $\alpha$ in the presence of ${ }^{32} \mathrm{P}$-labeled NF- $\kappa \mathrm{B}$ probe, followed by autoradiography. (C)DU-145 cells were transfected with control siRNA (Ctrl) or livin-targeted siRNA and after 40 min TNF- $\alpha$ treatment cell lysates $(30 \mu \mathrm{g})$ were subjected to Western blotting for phosphorylationI $\mathrm{B} \alpha$ analysis as described. (D) DU-145 cells were transfected with control siRNA (Ctrl) or livin-targeted siRNA and after 40 min TNF- $\alpha$ treatment cell lysates $(30 \mu \mathrm{g})$ were subjected to Western blotting for fibronectin protein analysis as described. (E) DU-145 cells were transfected with control siRNA (Ctrl) or p65-targeted siRNA and cell ly sates $(30 \mu \mathrm{g})$ were subjected to Western blotting for $\mathrm{p} 65$ protein analysis as described. (F) DU-145 cells were transfected with control siRNA (Ctrl) or p65-targeted siRNA and cell lysates $(30 \mu \mathrm{g})$ were subjected to Western blotting for fibronectin protein analysis as described. (G) DU-145 cells transfected with either the control siRNA or p65-targeted siRNA Matrigel invasion was analyzed by DAPI staining and quantified, in duplicate. ${ }^{*} \mathrm{P}<0.002$, compared with the control siRNA.

transfected with control siRNA exhibited a >100-fold upregulation of fibronectin mRNA, by real-time PCR (Fig. 4A), and increased fibronectin promoter activity, as assessed by luciferase reporter assay (Fig. 4B), compared to DU-145 cells transfected with livin-siRNA. Collagen type $1 \alpha 1$, collagen type $5 \alpha 2$ and

$N F-\kappa B$-induction of fibronectin contributes to livin-mediated tumor cell invasion. Several studies have reported compelling evidence that the transcription factor $\mathrm{NF}-\kappa \mathrm{B}$ plays a role in the control of oncogenesis, tumor progression and invasion (25-29). We next asked how livin may transcriptionally upregulate fibronectin, and we focused on a potential role of NF- $\mathrm{B}$ in this response.

We analyzed the role of $\mathrm{NF}-\kappa \mathrm{B}$ activation induced by TNF- $\alpha$ in DU-145 cells using luciferase-based NF- $\kappa B$ reporter assay. We first examined the time-course of TNF- $\alpha$-induced $N F-\kappa B$ activation by $N F-\kappa B$ reporter assay. At $3 h$ of TNF- $\alpha$ treatment resulted in $\sim 4$-fold $N F-\kappa B$ activation, and at $5 \mathrm{~h}$ over 8-fold activation was observed (data not shown), but at this time point the cells started to show signs of cell death. Therefore, we selected the $3 \mathrm{~h} \mathrm{TNF}-\alpha$ treatment in our NF- $\kappa \mathrm{B}$ reporter assay. As shown in Fig. $5 \mathrm{~A}$, TNF- $\alpha$-induced NF- $\kappa \mathrm{B}$ activation was induced by $>55 \%$ in the DU-145 cells transfected with livin-siRNA, whereas in the DU-145 cell there was no such effect.

By EMSA, a radiolabeled NF- $\kappa \mathrm{B}$ probe bound to nuclear extracts in DU-145 cells or DU-145 cells transfected with livin-siRNA, we found that TNF- $\alpha$-induced $N F-\kappa B$ activation inhibited remarkably the DU-145 cells transfected with livinsiRNA, compared with the control DU-145 cells (Fig. 5B). Confirmed with the results of EMSA, the expression of TNF- $\alpha$-induced phosphorylation, I $\kappa \mathrm{B} \alpha$ in the livin-siRNA groups were significantly lower than the ones in control group (Fig. 5C).

Next, we found that TNF- $\alpha$ stimulation of DU-145 cells or DU-145 cells transfected with livin-siRNA resulted in increased fibronectin expression, albeit more prominently in DU-145 cells (Fig. 5D). Conversely, siRNA knockdown of p65 NF- $\kappa \mathrm{B}$ (Fig. 5E) suppressed endogenous fibronectin expression in DU-145 cells, as compared with control siRNA (Fig. 5F). Similarly, siRNA silencing of livin also comparably suppressed fibronectin expression in DU-145 cells (Fig. 4C). 
Functionally, siRNA knockdown of p65 NF-кB inhibited Matrigel invasion of DU-145 cells, as compared with control transfectants (Fig. 5G). These data indicated that NF-кBinduction of fibronectin could be critical in livin-mediated tumor cell invasion.

\section{Discussion}

Numerous studies have validated that livin upregulation is a risk factor for cancer progression and prognostic prediction. Most studies on livin have focused on its role as a caspase inhibitor of caspase-3, -7, and -9, as well as by its E3 ubiquitin-ligase-like activity that promotes degradation of Smac/DIABLO, a critical endogenous regulator of all IAPs $(12,13)$. There is increasing evidence that it also acts via other mechanisms like other IAP members $(14,15)$. It was reported that beyond their roles in cytoprotection, it is now clear that IAPs function as broader regulators of cellular homeostasis, intercalated in cell division, metabolism and activation of multiple intracellular signaling pathways, including NF- $\kappa B$, TGF- $\beta$ or JNK (7). In this study, we investigate whether livin signaling affected metastasis and the results showed that siRNA targeting to livin transfection into the DU-145 cell line confirmed the anti-tumor-invasion effect and supression of livin gene. We demonstrated that siRNA knockdown of fibronectin significantly inhibited tumor cell invasion (Fig. 4F). Based on these data we deduced that fibronectin played an important role in livin-mediated tumor cell invasion. Next we found that livin induction of fibronectin regulates tumor cell invasion via NF- $\mathrm{kB}$ signaling.

Some studies have reported that outside-in signaling mediated by $\beta 1$ integrins (30), leads to phosphorylation of Src (31), FAK (32), and mediates tumor cell invasion, in vivo (33). Our data presented here suggest fibronectin as a direct mediator of tumor cell invasion via NF- $\kappa B$ signalling. As an abundant constituents of the extracellular matrix, fibronectin binds multiple integrins (34), resulting in the activation of focal adhesion kinase (FAK) (32), Src (35), Akt (36), as well as modulation of small GTPases of the Rho family (37). Whether livin is involved in this cellular network orchestrated by these molecules and thus inhibited tumor invasion need to be investigated further. Previously it was reported that intermolecular cooperation between IAP proteins, XIAP and survivin, promotes tumor cell invasion in vitro and metastatic dissemination in vivo (7). Livin is an important member of IAPs family and IAPs family members may cooperate with each other to promote tumor cell invasion. Therefore, whether livin could cooperate with other members of IAPs family, such as XIAP, cIAPs and survivin needs clarification.

Previously, a link between NF- $\mathrm{kB}$ activity and metastasis has been established to stimulation of epithelial-mesenchymal transition (EMT), expression of matrix metalloproteinase-9 (MMP-9), or repression of putative metastasis-suppressor genes (38). MMPs are a family of zinc-dependent metallo-endopeptidases that aid in the degradation of the components of the ECM (39). Abnormal degradation rates often make cells more anchorage-independent and lead to cancer. The MMP pathways have also been responsible under various conditions to enhance the progression of a malignant phenotype. We do not know yet whether livin is involved in the activation/inhibition of the MMP pathway and metastasis.
In summary, we studied whether livin signaling affected metastasis by transfecting siRNA targeting livin into the DU-145 cancer cell line to confirm the anti-tumor-invasion effect and supression of the livin gene. We next identified that livin induction of fibronectin regulates tumor cell invasion via $\mathrm{NF}-\kappa \mathrm{B}$ signaling. It was reported that livin expression was significantly increased in a series of cancers (17-20). Moreover, studies of biopsies from some cancers reported that livin is detected in these tumor samples, but not in the corresponding normal tissues. The relative overexpression indicates that livin represents a therapeutic target to increase the apoptotic sensitivity of cancer cells. Our data indicate livin as direct metastasis gene being useful for therapeutic intervention against advanced and disseminated PCa.

\section{Acknowledgements}

This study was supported by the grant from the National Nature and Science Foundation of China (no. 30670544), and Dr Liaoning province start funds (20111112).

\section{References}

1. Jemal A, Siegel R, Ward E, Hao Y, Xu J and Thun MJ: Cancer statistics, 2009. CA Cancer J Clin 59: 225-249, 2009.

2. Sim HG and Cheng CW: Changing demography of prostate cancer in Asia. Eur J Cancer 41: 834-845, 2005.

3. Denmeade SR, Lin XS and Isaacs JT: Role of programmed (apoptotic) cell death during the progression and therapy for prostate cancer. Prostate 28: 251-265, 1996.

4. Mehlen P and Puisieux A: Metastasis: a question of life or death. Nat Rev Cancer 6: 449-458, 2006.

5. Cory S and Adams JM: The Bcl2 family: regulators of the cellular life-or-death switch. Nat Rev Cancer 2: 647-656, 2002.

6. Gyrd-Hansen M and Meier P: IAPs: from caspase inhibitors to modulators of NF-kappaB, inflammation and cancer. Nat Rev Cancer 10: 561-574, 2010.

7. Srinivasula SM and Ashwell JD: IAPs: what's in a name? Mol Cell 30: 123-135, 2008.

8. Dubrez-Daloz L, Dupoux A and Cartier J: IAPs: More than just inhibitors of apoptosis proteins. Cell Cycle 7: 1036-1046, 2008.

9. Vucic D, Stennicke HR and Pisabarro MT: ML-IAP, a novel inhibitor of apoptosis that is preferentially expressed in human melanomas. Curr Biol 10: 1359-1366, 2000

10. Franklin MC, Kadkhodayan S and Ackerly H: Structure and function analysis of peptide antagonists of melanoma inhibitor of apoptosis (ML-IAP). Biochemistry 42: 8223-8231, 2003.

11. Kasof GM and Gomes BC: Livin, a novel inhibitor of apoptosis protein family member. J Bio Chem 276: 3238-3246, 2001.

12. Chang $H$ and Schimmer AD: Livin/melanoma inhibitor of apoptosis protein as a potential therapeutic target for the treatment of malignancy. Mol Cancer Ther 6: 24-30, 2007.

13. Ma L, Huang Y and Song Z: Livin promotes Smac/DIABLO degradation by ubiquitin-proteasome pathway. Cell Death Differ 13: 2079-2088, 2006.

14. Sanna MG, da Silva Correia J and Ducrey O: IAP suppression of apoptosis involves distinct mechanisms: the TAK1/JNK1 signaling cascade and caspase inhibition. Mol Cell Biol 22: 1754-1766, 2002.

15. Uematsu K, He B, You L, Xu Z, McCormick F and Jablons DM: Activation of the Wnt pathway in non small cell lung cancer: evidence of disheveled overexpression. Oncogene 22: 7218-7221, 2003.

16. Lin JH, Deng G and Huang Q: KIAP, a novel member of the inhibitor of apoptosis protein family. Biochem Biophys Res Commun 279: 820-831, 2000.

17. Wang $\mathrm{X}, \mathrm{Xu} \mathrm{J}$ and Ju S: Livin gene plays a role in drug resistance of colon cancer cells. Clin Biochem 43: 655-660, 2010.

18. Qiuping Z, Jei X and Youxin J: CC chemokine ligand 25 enhances resistance to apoptosis in CD4? T cells from patients with T-cell lineage acute and chronic lymphocytic leukemia by means of livin activation. Cancer Res 64: 7579-7587, 2004. 
19. Choi J, Hwang YK and Sung KW: Expression of Livin, an antiapoptotic protein, is an independent favorable prognostic factor in childhood acute lymphoblastic leukemia. Blood 109: 471-477, 2007.

20. Gazzaniga P, Gradilone A and Giuliani L: Expression and prognostic significance of Livin, survivin and other apoptosisrelated genes in the progression of superficial bladder cancer. Ann Oncol 14: 85-90, 2003.

21. Song T, Hong BF, Gao JP, Zhang L and Cai W: Expression of apoptosis inhibitor gene Livin in prostate cancer and its clinical implication. Zhonghua Nan Ke Xue 14: 30-33, 2008 (In Chinese).

22. Mehrotra S, Languino LR, Raskett CM, Mercurio AM, Dohi T and Altieri DC: IAP regulation of metastasis. Cancer Cell 17: 53-64, 2010.

23. Oh BY, Lee RA and Kim KH: siRNA targeting Livin decreases tumor in a xenograft model for colon cancer. World J Gastroenterol 17: 2563-2571, 2011

24. Jutooru I, Chadalapaka G, Lei P and Safe S: Inhibition of NF-kappaB and pancreatic cancer cell and tumor growth by curcumin is dependent on specificity protein down-regulation. J Biol Chem 285: 25332-25344, 2010.

25. Barkett $\mathrm{M}$ and Gilmore TD: Control of apoptosis by Rel/NF- $\kappa \mathrm{B}$ transcription factors. Oncogene 18: 6910-6924, 1999.

26. Rayet $B$ and Gélinas $C$ : Aberrant rel/NF- $\kappa B$ genes and activity in human cancer. Oncogene 18: 6938-6947, 1999.

27. Nakanishi C and Toi M: Nuclear factor-kappaB inhibitors as sensitizers to anticancer drugs. Nat Rev Cancer 5: 297-309, 2005.

28. Baud V and Karin M: Is NF- $\kappa B$ a good target for cancer therapy? Hopes and pitfalls. Nat Rev Drug Discov 8: 33-40, 2009.

29. Aggarwal BB: Nuclear factor-kappaB: the enemy within. Cancer Cell 6: 203-208, 2004.
30. Ginsberg $\mathrm{MH}$, Partridge A and Shattil SJ: Integrin regulation. Curr Opin Cell Biol 17: 509-516, 2005.

31. Mitra SK and Schlaepfer DD: Integrin-regulated FAK-Src signaling in normal and cancer cells. Curr Opin Cell Biol 18: 516-523, 2006.

32. Sieg DJ, Hauck CR, Ilic D, Klingbeil CK, Schaefer E, Damsky CH and Schlaepfer DD: FAK integrates growth-factor and integrin signals to promote cell migration. Nat Cell Biol 2: 249-256, 2000.

33. Parsons JT, Slack-Davis J, Tilghman R and Roberts WG: Focal adhesion kinase: targeting adhesion signaling pathways for therapeutic intervention. Clin Cancer Res 14: 627-632, 2008.

34. Cukierman E, Pankov R and Yamada KM: Cell interactions with three-dimensional matrices. Curr Opin Cell Biol 14: 633-639, 2002.

35. Yeatman TJ: A renaissance for SRC. Nat Rev Cancer 4: 470-480, 2004.

36. Irie HY, Pearline RV, Grueneberg D, Hsia M, Ravichandran P, Kothari N, Natesan S and Brugge JS: Distinct roles of Akt1 and Akt2 in regulating cell migration and epithelial-mesenchymal transition. J Cell Biol 171: 1023-1034, 2005.

37. Nobes CD and Hall A: Rho, rac, and cdc42 GTPases regulate the assembly of multimolecular focal complexes associated with actin stress fibers, lamellipodia, and filopodia. Cell 81: 53-62, 1995.

38. Naugler WE and Karin M: NF-kappaB and cancer-identifying targets and mechanisms. Curr Opin Genet Dev 18: 19-26, 2008.

39. Munshi HG and Stack MS: Reciprocal interactions between adhesion receptor signaling and MMP regulation. Cancer Metastasis Rev 25: 45-56, 2006. 